\title{
Evaluation of prevalence, distribution and types of drug errors reported in Besat Medical Center of Hamadan during 2014-2015
}

\author{
Farnaz Hashemian', Mahnaz Farzian', Mohammad Hossein Bakhshaei ${ }^{3}$ \\ ${ }^{I}$ Associate professor, Otolaryngology Department, School of Medicine, Hamadan University of Medical Sciences, \\ Hamadan, Iran \\ ${ }^{2}$ MSc of Nursing, Clinical Supervisor, Besat hospital, Hamadan, Iran \\ ${ }^{3}$ Associate Professor, Anesthesiology Department, School of Medicine, Hamadan University of Medical Sciences, \\ Hamadan, Iran
}

\begin{abstract} drug errors among medical and nursing team. occurrence. lower incidence of drug errors. 29(3): 267-274.

Correspondence to: Mohammad Hossein Bakhshaei

Tel: +989188129971

E-mail: bakhshaei@umsha.ac.ir

ORCID ID: 0000-0002-3820-2447

Received: 02 Dec 2018; Accepted: 17 Feb 2019
\end{abstract}

Background: Regarding the high frequency of drug errors and its importance in increasing financial costs and health of the patients, this study was conducted with the aim of determining the prevalence and types of

Materials and methods: In this cross -sectional study, of 903 medical errors, 385 reported drug errors were recorded in safety unit and mortality and morbidity committee of Besat Hospital in Hamadan during 20142015. The data were gathered in a checklist, including the types of drug errors, the wards and time of

Results: Of the 903 reported medical errors totally, only 385 drug errors was reported (42.6\%). The most errors were in dose of medicines $(22.8 \%)$ and false timing of drug delivery $(19.7 \%)$. The highest rate of drug error was reported in surgical $(11.6 \%)$ and pediatrics $(9.8 \%)$ wards.

Conclusion: The results showed that improving pharmacologic knowledge of nurses and physicians is important on of the patients' safety. It is required to implement credit scales by the management team to

Keywords: Drug error, Medical wards, Medical team errors.

Cited as: Hashemian F, Farzian M, Bakhshaei MH. Evaluation of prevalence, distribution and types of drug errors reported in Besat Medical Center of Hamadan during 2014-2015. Medical Science Journal of Islamic Azad University, Tehran Medical Branch 2019; 
مجله علوم يزشكى دانشعاه آزاد اسلامى

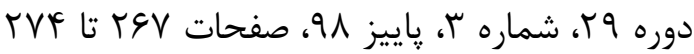

\title{
ارزيابى فراوانى، توزيع و انواع خطاهاى دارويى كزارش شده در مركز آموزشى درمانى بعثت همدان طى سالهاى
}

\author{
فرناز هاشميان'، مهرنازفرضيان؟، محمد حسين بخشايیى
}
'دانشيار، كروه كوش و حلق و بينى، دانشكده يزشكى، دانشكاه علوم يزشكى همدان، ايران

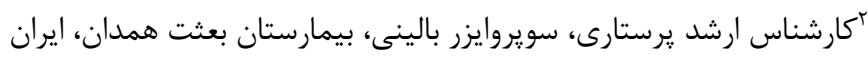

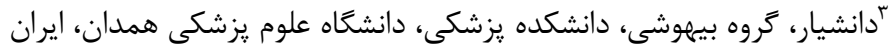

جكيده

سابقه و هدف: : با توجه به شيوع انواع خطاهاى دارويى، /ين مطالعه با هدف تعيين ميزان فراوانى، توزيع و انواع خطاهاى دارويى كزارش شده انجام شد.

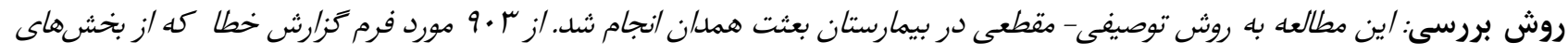

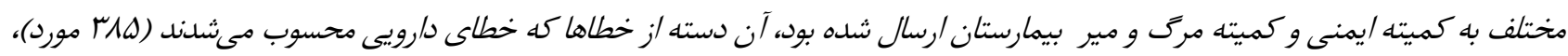

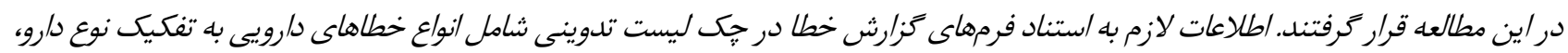

$$
\text { بخش، ميزان ريسك و زمان بروز جمع آورى شلد. }
$$

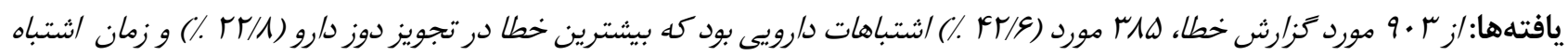

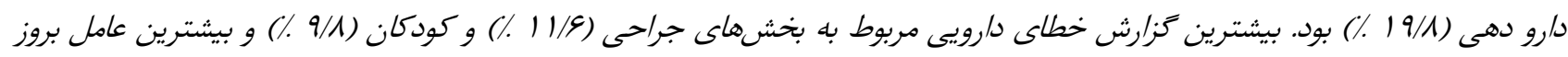

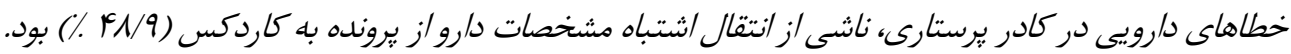

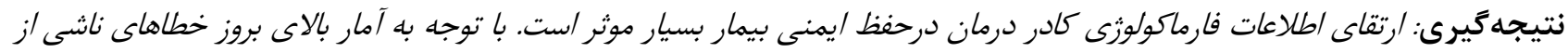

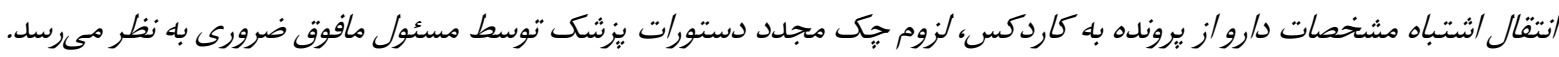

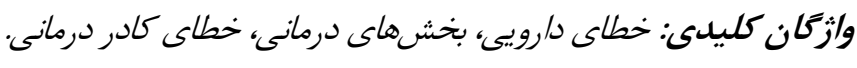

انجام دهند (1). خطاهاى تيم يزشكى، امرى اجتناب نايذير و

مقدمه

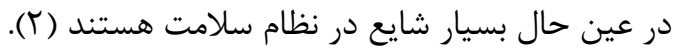

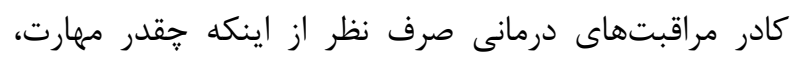

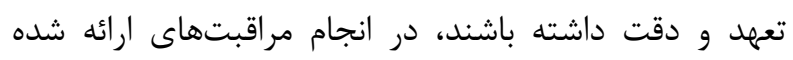
دجار اشتباه مىشوند و بسيارى از خطاها از فرايندهاى

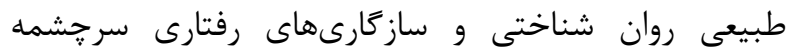

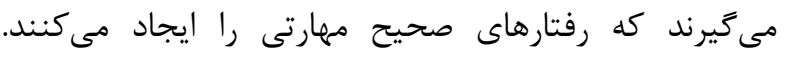

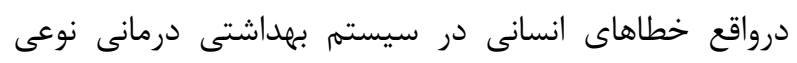

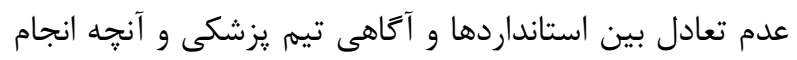

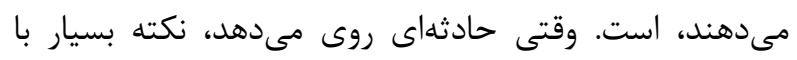

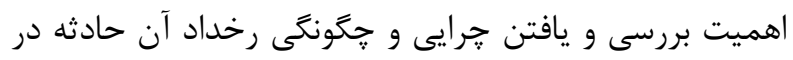

خطاى تيم يزشكى عمل يا تصميمى است كه با استانداردهاى

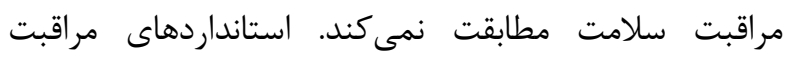

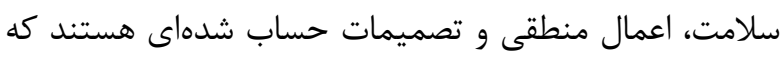
مسئولين مراقبت سلامت با توجه به شرايط و مقتضيات بايد

آدرس نويسنده مسئول: همدان، دانشكاه علوم بزشكى همدان ، كـروه بيهوشسى، محمـا حسـين بخشـايى (email: : bakhshaei@umsha.ac.ir) ORCID ID: 0000-0002-3820-2447 تاريخ دريافت مقاله: 9V/9/II

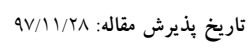




\section{مواد و روشها}

اين مطالعه بـه روش توصـيفى - مقطعى (Cross sectional) در

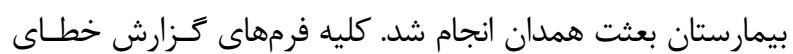

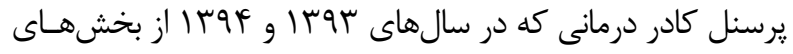

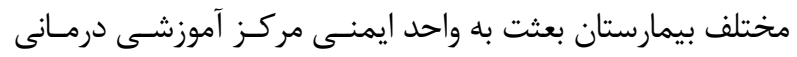

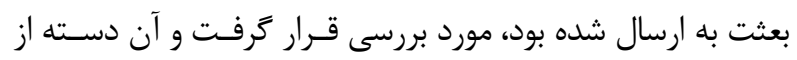
خطاها كه خطاى دارويى محسوب مىشدند در ايسن مطالعـه قـرار كرفتند. تعداد نمونه هاى واجد شرايط هیّ مورد بود.

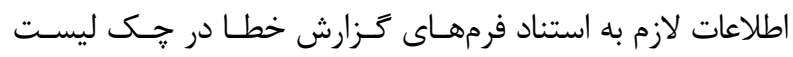

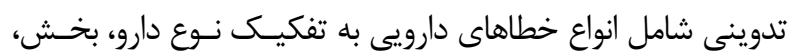
ميزان ريسك و زمان بروز ثبت شد. اشتباهات دارويى در دو گروه يزشكى و يرستارى به صورئ صورت مجزا

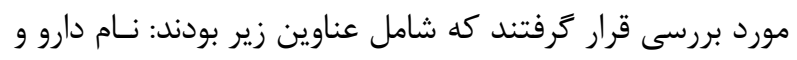

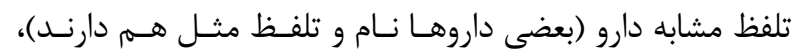
دستور اشتباه، دوز و زمــان اشـتباه، بيمـار اشـتباه، روش تجـويز

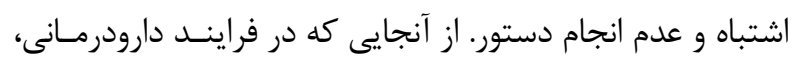
انتقال از يرونده به كاردكس يكى از مههمترين فعاليتها به شـمار

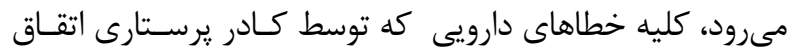

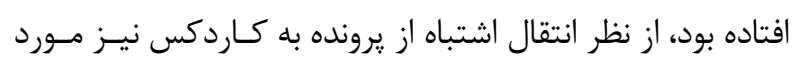
بررسى قرار زرفتند. در نهايت كليه خطاها از نظر ميزان بروز ريسـك و شـيفت بـروز

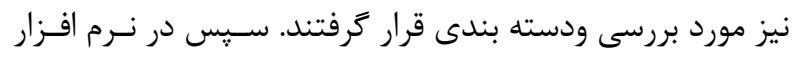

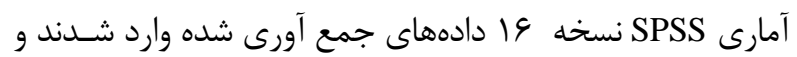

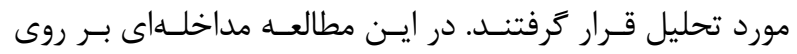

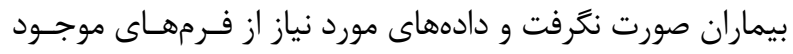
در واحد ايمنى استخراج شد. ملاحظات اخلاقى با عدم ثبت نـام

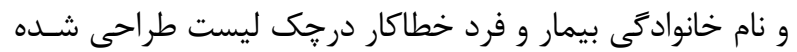
رعايت شد.

\section{يافتهها}

نتايج نشان داد كه از بين ب•9 مورد خطاى كزارش شده

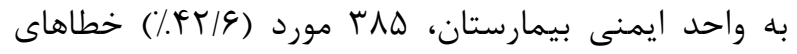
دارويى بودند. بيشترين فراوانى ززارش خطا در بخشهاى

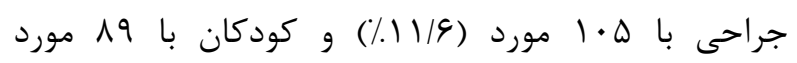

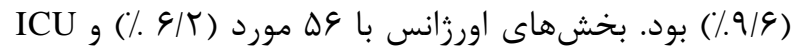

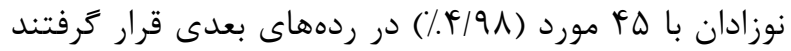

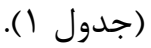

سيستم است. بايد به دنبال نقاط ضعف سيستم (مديريت،

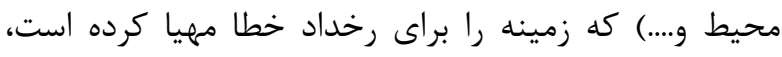
باشيه. نتيجه اوليه و طبيعى هر خطايى افزايش مدت بسترى بيمار و نيز افزايش هزينههاست. در بعضى موارد نيز ممكن است منجر به آسيب شديد و يا حتى مرى بيمار شود. مسائلى

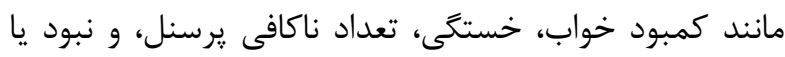
كمبود وسايل از جمله مسايل ينهانى هستند كه به طور غيرمستقيم در بروز خطا نقش دارند (r). دادن دارو خطرناكترين وظيفه يرستار است كه خطا در انجام آن مىتواند ييامدهاى بسيار نامطلوبى براى بيمار به دنبال داشته باشد. خطاى دارويى يك مشكل قديمى و بسيار شايع است. امروزه، يكى از مفاهيم اساسى در سيستمهاى ارائه

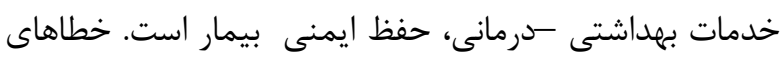
دارويى را به دليل شايعترين فرايندى كه در بيمارستانها انجام مىشود مىتوان جزء شايعترين خطاها محسوب كرد.

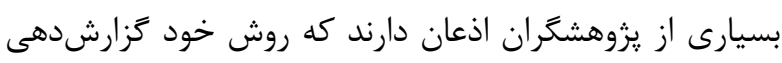

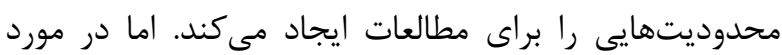
خطاهاى دارويى، يكى از متداولترين و عملىترين راهها،

شناسايى و تخمين خطاهاى صورت گرفته است (أ). امروزه اساسىترين آيتم در درمان، حفظ ايمنى است. بروز اشتباهات علاوه بر آسيب به بيمار، افزايش مدت بسترى، هدر رفتن نيروى انسانى، افزايش هزينه بيمار، تحميل بار مالى به

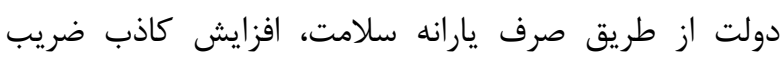
اشغال تخت و كاهى اوقات مرى را به دنبال خواهد داشت كه موجب سلب اعتماد و به دنبال آن نارضايتى بيماران از سيستم ارائه دهنده خدمت مىشود و مى تواند منجر به ايجاد استرس و

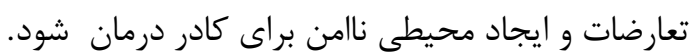
با توجه به شيوع انواع خطاهاى دارويى و اهميت آن در

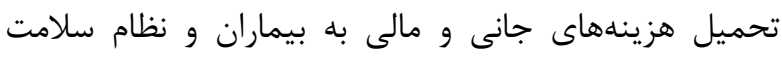

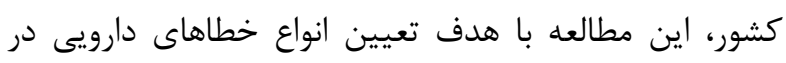

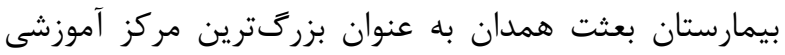

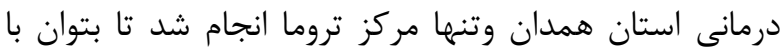
شناسايى شايعترين خطاهاى دارويى حادث به سيستم كمك هم

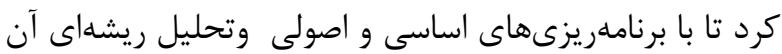
و اصلاح فرايندهاى معيوب از بروز مجدد آنها بيشخيرى كرد و باكاهش خطاها در جهت تامين رضايت و امنيت بيماران كام برداشت. 


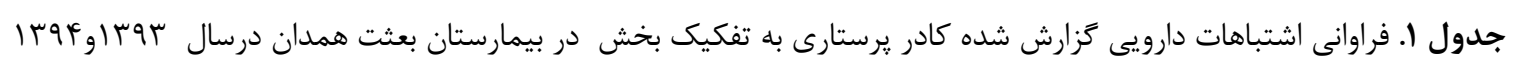

\begin{tabular}{|c|c|c|c|c|}
\hline \multirow[t]{2}{*}{ درصد از كل سهr مورد خطاى درويى در بخش مربوطه } & \multicolumn{2}{|c|}{ ناشى از انتقال اشتباه از يرونده به كاردكس } & كل خطاى دارويى كادر & \multirow[t]{2}{*}{ بخش } \\
\hline & درصد از تعداد خطا در بخش مربوطه & 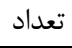 & ت تعداد & \\
\hline$r / 1 r$ & $\Delta \wedge$ & 11 & 19 & 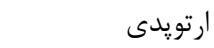 \\
\hline $11 / \mu F$ & FF/GQ & f. & 94 & جراحى \\
\hline$|f /| V$ & $4 \cdot \pi F$ & $\Delta \cdot$ & ᄉr & 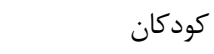 \\
\hline$r / T V$ & $\wedge$. & $\wedge$ & $1 \cdot$ & جراحى مغزواعصاب \\
\hline$F / T \Delta$ & $q \mu / V \Delta$ & 10 & 19 & فك وصورت \\
\hline$\cdot$ & $\cdot$ & $\cdot$ & $\Delta$ & اتاق عمل \\
\hline$V / T V$ & $4 q$ & rq & $\Delta r$ & اورزانس - انس \\
\hline$\cdot / 49$ & $\Delta \cdot$ & 1 & r & سوختكى \\
\hline $1 / 1 F$ & ra & f & 19 & تروما \\
\hline $1 / 1 F$ & r. & r & $1 \cdot$ & قلب \\
\hline$\cdot / 49$ & $\Delta \cdot$ & 1 & r & جنرال ICU \\
\hline$\cdot / 49$ & $1 \cdots$ & 1 & 1 & اطفال ICU \\
\hline$V / 99$ & $9 V / 0$ & TV & $r \cdot$ & ICU \\
\hline$\cdot$ & $\cdot$ & $\cdot$ & $\cdot$ & دياليز \\
\hline$\cdot$ & $\cdot$ & $\cdot$ & $\cdot$ & ENT \\
\hline$\Delta r / T$ & $\Delta r / r$ & 111 & $r \Delta r$ & مجموع \\
\hline
\end{tabular}

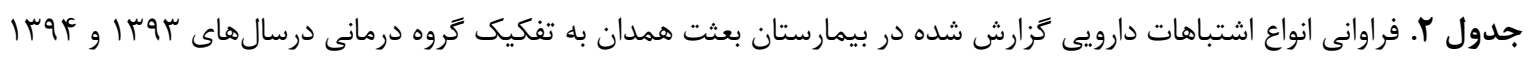

\begin{tabular}{|c|c|c|c|c|c|c|}
\hline \multicolumn{2}{|c|}{ تعدادكل } & \multicolumn{2}{|c|}{ يرستارى } & \multicolumn{2}{|c|}{ يزشكى } & \multirow[b]{2}{*}{ نوع خطا } \\
\hline درصد & تعداد & درصد & تعداد & درصد & تعداد & \\
\hline $1 \pi / \Delta$ & $\Delta r$ & $1 \pi / T$ & Q) & $\cdot \pi$ & 1 & نام وتلفظ مشابه \\
\hline $19 / V$ & ve & $19 / 6$ & $V \Delta$ & $\cdot / r$ & 1 & زمان اشتباه \\
\hline$r / 4$ & $1 \pi$ & $\cdot$ & · & $r / \varphi$ & Ir & دستور اشتباه \\
\hline$r T / \Lambda$ & $\Lambda \Lambda$ & $19 / V$ & ve & $r / 1$ & ir & دوز اشتباه \\
\hline$F / V$ & 11 & $F / V$ & 11 & · & · & بيمار اشتباه \\
\hline$\Delta / r$ & $r \cdot$ & $\Delta / r$ & $r \cdot$ & . & · & روش اشتباه \\
\hline 1911 & GT & $\mid F / \Lambda$ & $\Delta V$ & $1 / \pi$ & $\Delta$ & داروى اشتباه \\
\hline $1 f / \Delta$ & $\Delta \varphi$ & $\mid F / \Delta$ & $\Delta \varphi$ & $\cdot$ & . & عدم انجام دستور \\
\hline $1 \cdots$ & rAD & $91 / V$ & rar & $\Lambda / r$ & rT & مجموع \\
\hline
\end{tabular}

يرستارى بودند. در گروه يزشكى، بيشترين خطاى دارويى

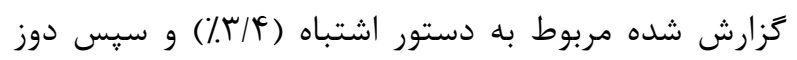

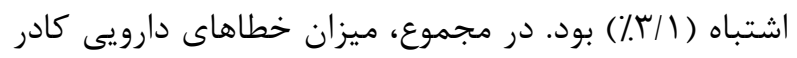

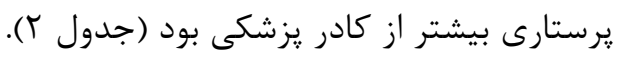

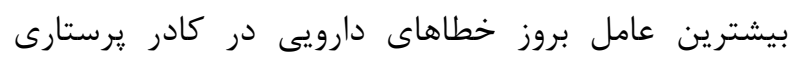

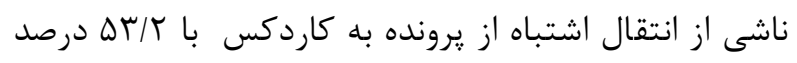

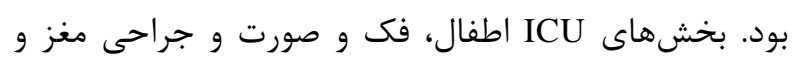

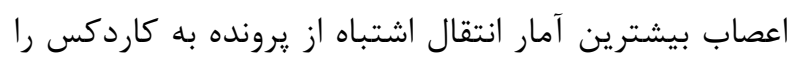

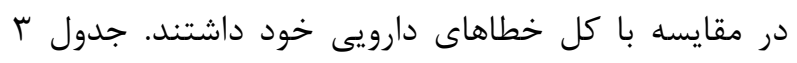

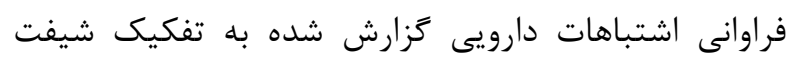

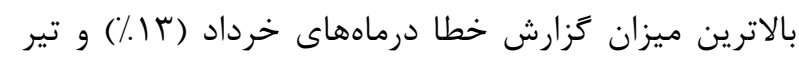

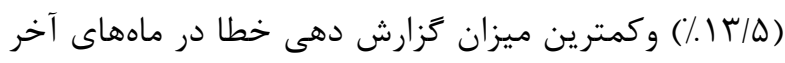

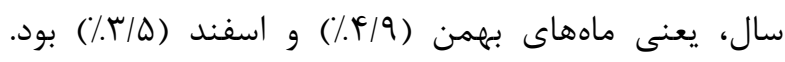

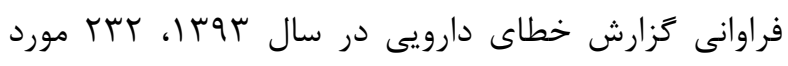

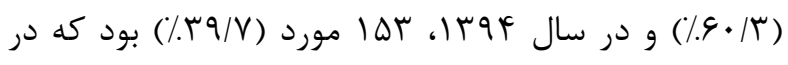

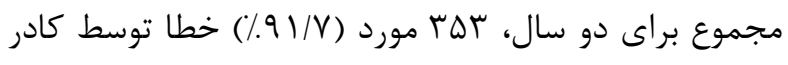
يرستارى ززارش شد.

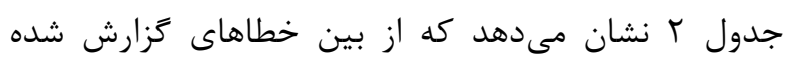

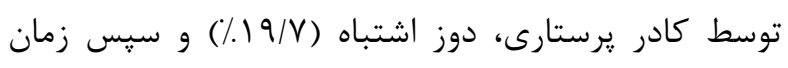

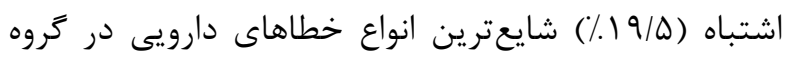


سيستم مشخص ثبت وكزارش دهى صحيح خطاها است كه

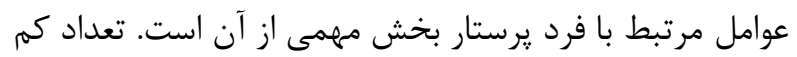

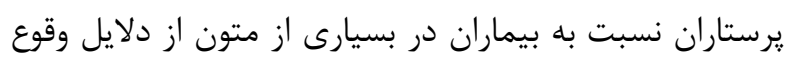
خطاى يرستاران است. ميانكَين كزارش خطا در مطالعات انجام شده در ايران همواره

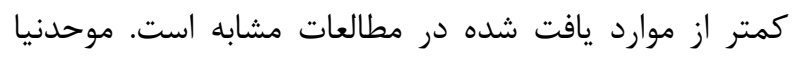
علت عدم كزارش خطا را عواملى نظير ترس از مواخذه و اطلاع

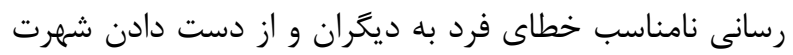
يا شغل وايجاد كار اضافى مطرح كرده است (؟).

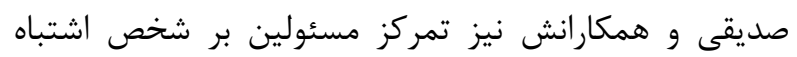

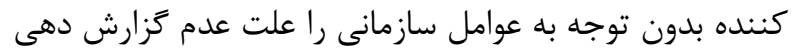

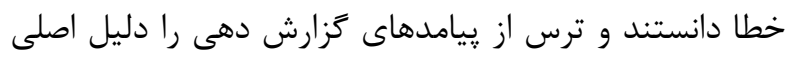
عدم تزارش خطا مطرح كردند (V) Banja دارويى كشف نمىشوند و موارد متعددى از خطاهاى كشف

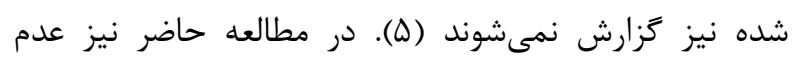

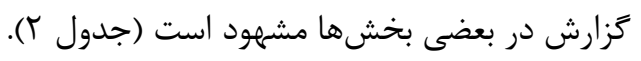
محسن زاده بر اساس مطالعه خود معتقد است كه بيشترين خطاى حادث در بيمارستانها از نوع دارويى است (^).

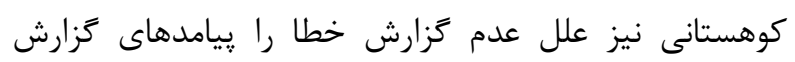
دهى دانست و عوامل سازمانى را بيشتر از عوامل انسانى و وارئ شخصى نيازمند اصلاح مى دانست (9).

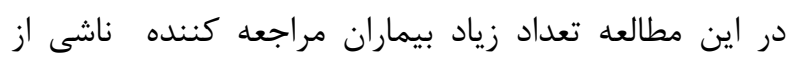

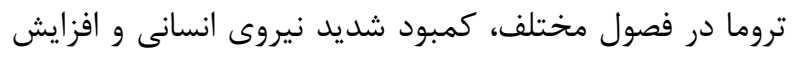
مستند سازىها به دنبال نهادينه كردن بسيارى از استانداردها

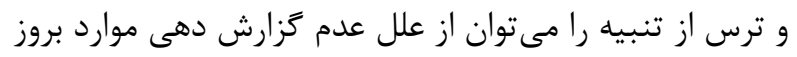

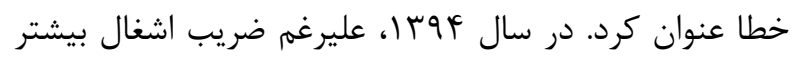

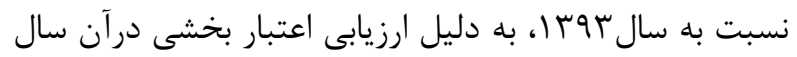

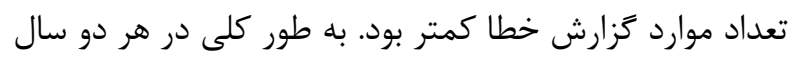

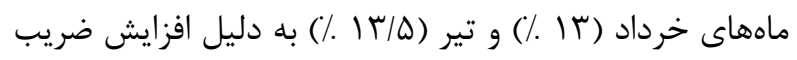
اشغال تخت به دنبال شروع تعطيلات و افزايش جراحىهاى

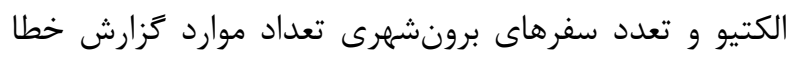

$$
\text { در هر دو سال بيشتر بود. }
$$

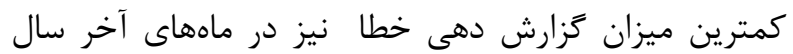

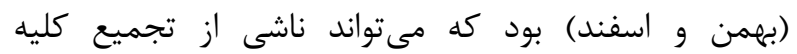
عملكر دهاى ساليانه در واحدها دانست.

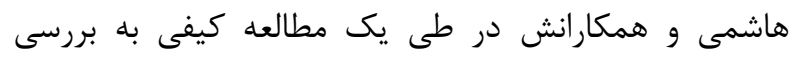

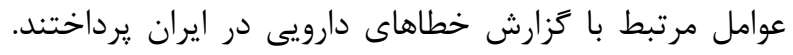

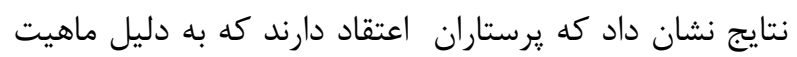

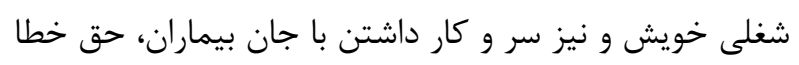

كارى را نشان مىدهد. بيشترين خطاى كزارش شده از نظر

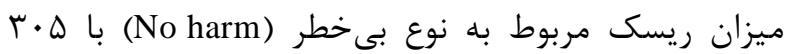

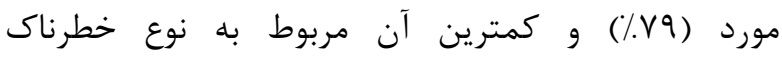

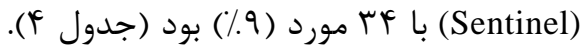

جدول r. فراوانى اشتباهات دارويى كزارش شده به تفكيك شيفت

\begin{tabular}{|c|c|c|}
\hline درصد & تعداد & شيفت \\
\hline Tr & ITD & صبح \\
\hline rQ & 91 & عصر \\
\hline FT & 184 & شب \\
\hline $1 \ldots$ & r^ब & مجموع \\
\hline
\end{tabular}
كارى در بيمارستان بعثت همدان درسال سوساو

جدول F. فراوانى خطاهاى كزارش شده دارويى براساس ميزان

\begin{tabular}{|c|c|c|}
\hline درصد & تعداد & ميزان ريسك \\
\hline ir & iq & نزديك به خطر \\
\hline vq & $r \cdot \Delta$ & بى خطر \\
\hline 9 & $r F$ & خطرناى \\
\hline $1 \ldots$ & rNA & كل \\
\hline
\end{tabular}

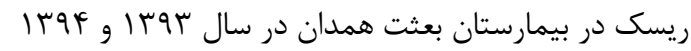

\section{بحث}

درمطالعه حاضر، از بين ب.9 مورد تزارش كل خطاهاى صورت

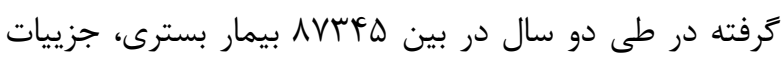
همب كزارش خطاهاى دارويى مورد بررسى قرار كرفت. Banja

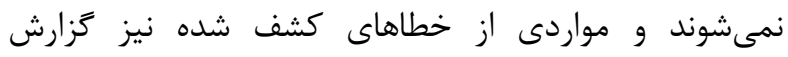

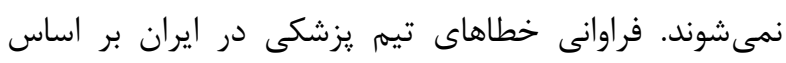

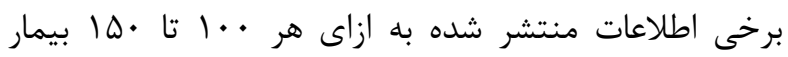

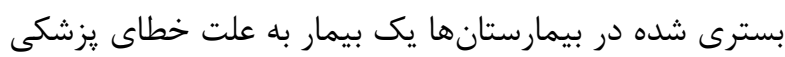

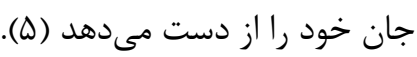

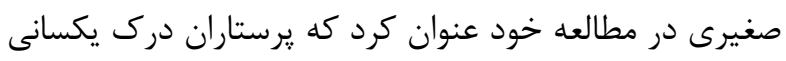

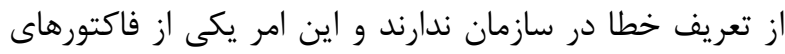

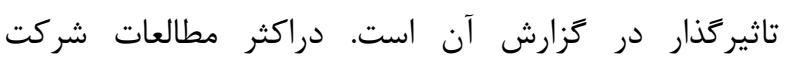

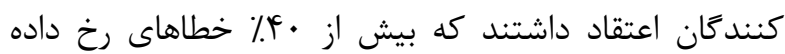
هرَز كزارش نمىشود و ترس مهممترين عامل عدم كزارش

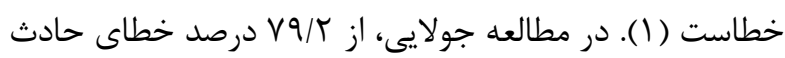

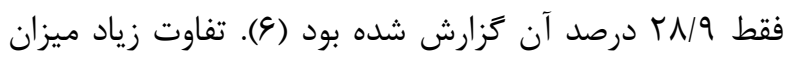

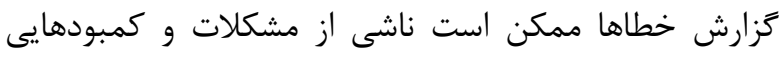

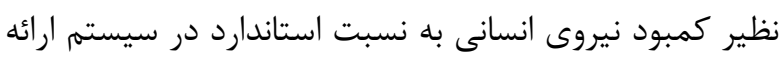
خدمت، عدم نظارت دقيق بر فرايند دارويى و عدم وجود نسيت نسئن 
بيماران، تعدد بذيرش و ترخيص بيماران در يك شيفت كارى و تعدد دوز دارويى) مرتبط باشد.

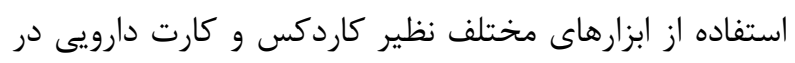

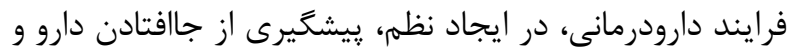

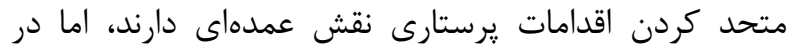

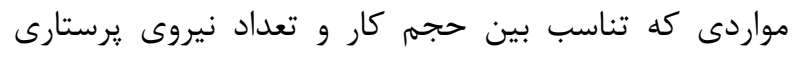

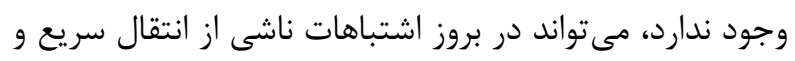

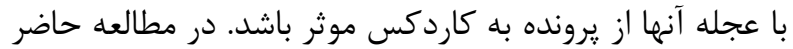

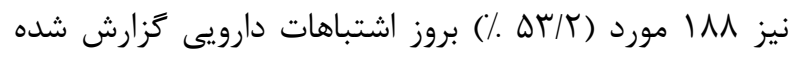

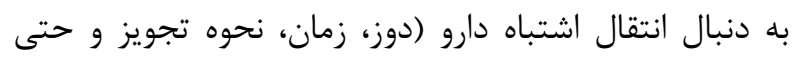

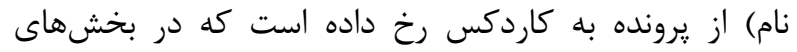

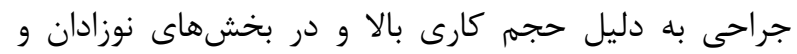

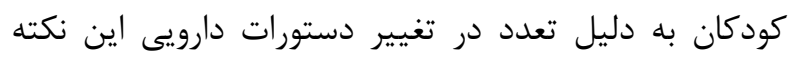

بيشتر به جشم مى خورد. براساس مطالعه كوهستانى، شايعترين نوع اشتباهات دارويى كزارش شده از سوى دانشجويان يرستارى، مقدار دارو، داروى

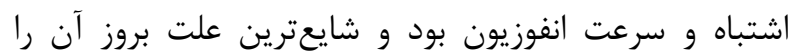
اشتباه وارد كردن دارو از يرونده به كاردكس نام برد (9). محمدنزاد و همكارانش نيز شايعترين علل بروز خطار برد ردار را اشتباه

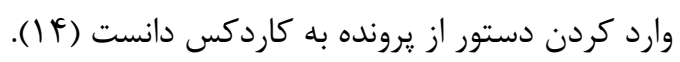

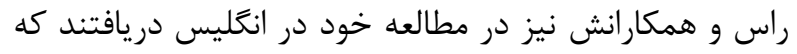

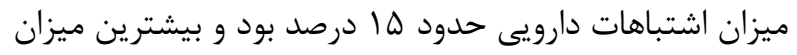

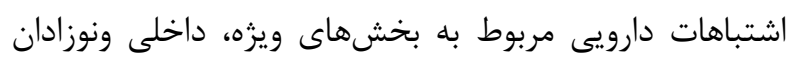

بود (I) - (I). براساس مطالعه باقريان و همكاران در اصفهان، بيشترين

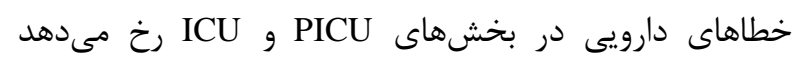

براساس مطالعه محمدنزاد و همكارانش بيشترين محل

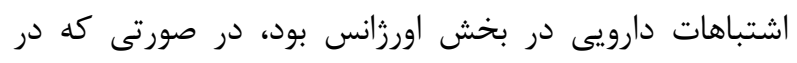

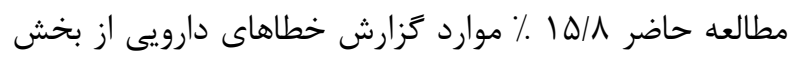

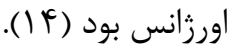

رعايت اصول هشت گانه تجويز دارو، شامل روش صحيح، بيمار صحيح، داروى صحيح، مقدار صحيح، زمان صحيح، تجويز

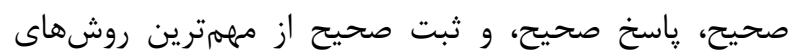

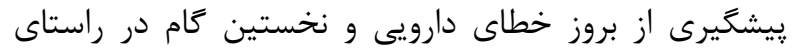

تحقق ايمنى بيمار و اجراى صحيح دارودرمانى است.

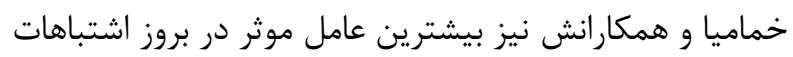
دارويى را كمبود اطلاعات دارويى يرستاران عنوان كردند و 19 درصد اشتباهات را به علت محاسبات غلط دوز دارو كزارش

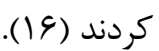

كردن ندارند و اكثر آنها معتقد بودند كه در صورتى كه خطاى

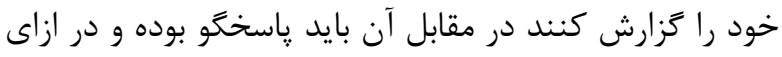

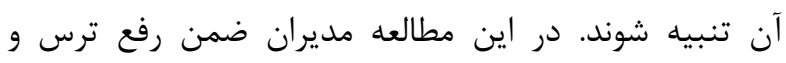

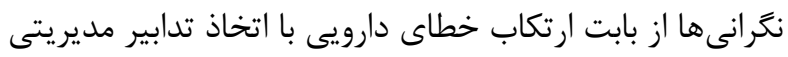

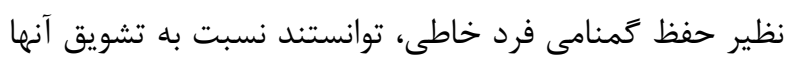

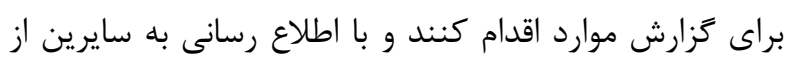

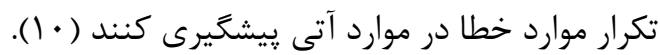

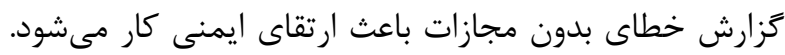

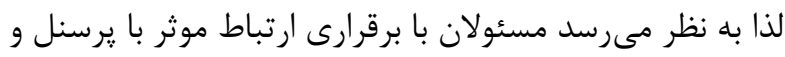

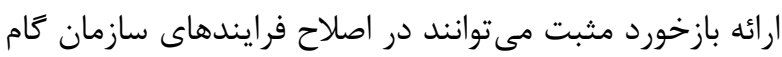

$$
\text { مفيدى بردارند. }
$$

بديهى است كه بيشگيرى از خطاها بستخى به كزارش دارن دقيق

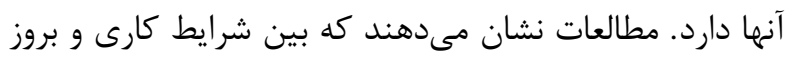
خطا ارتباط معنىدارى وجود دارد، اما دراين مطالعه اين

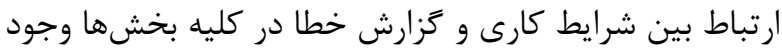

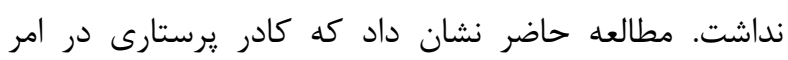

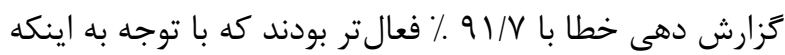
فرايند دارودرمانى بيشتر توسط كادر يرستارى انجام مى شود باردا

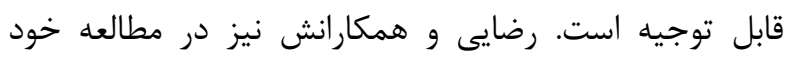

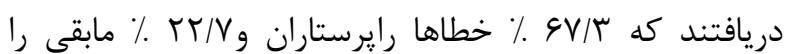
يزشكان مرتكب مىشوند (1 (1). راس و همكارانش در انغليس

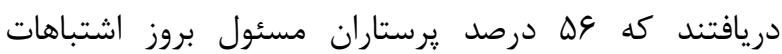

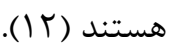

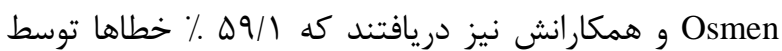

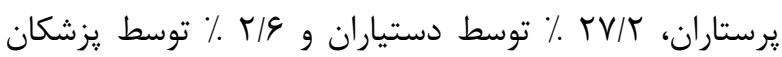
بروز مى كند (با) (1).

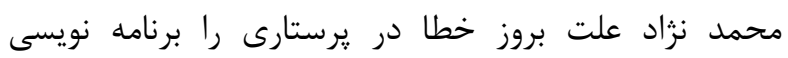

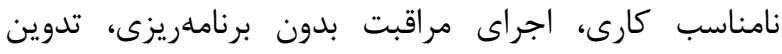

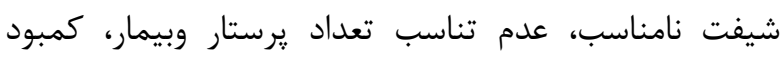
امكانات و شيفت كارى شبانه دانست (fi ( ). يزوهشكران اين مطالعه دريافتند كه خطا در تجويز دوز دارو

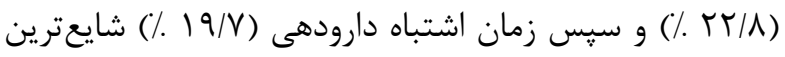

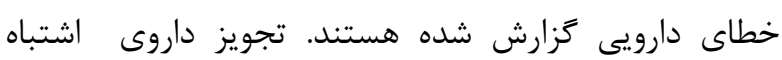

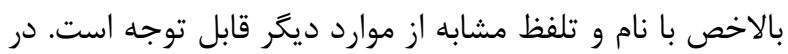

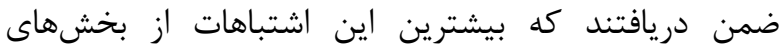

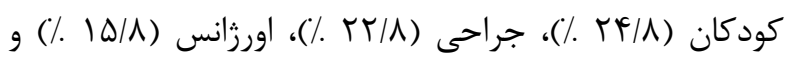
نوزادان (T/Y ICU

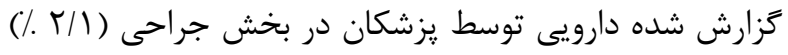

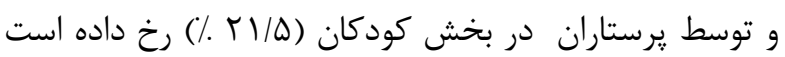
كه علت آن مىتواند به ماهيت بخشهار دران (حاد بودن شرايط ريط 
است كه از طريق كميته مرگ و مير شناسايى شده است. با

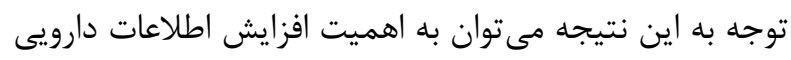

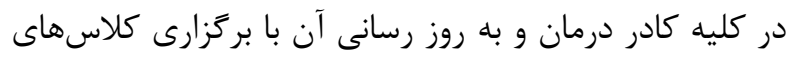

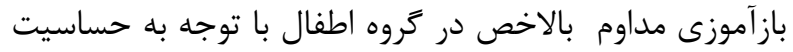

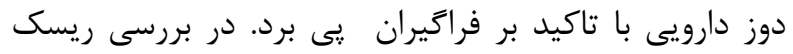

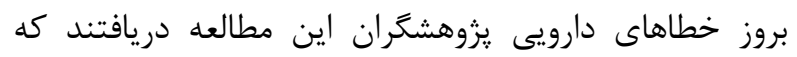

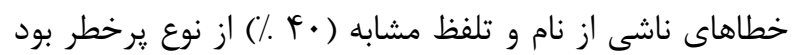

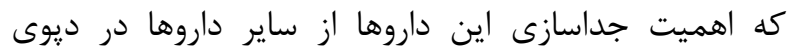

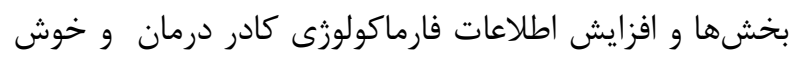
خط نويسى دستورات را بيان مى كند.

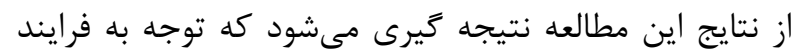

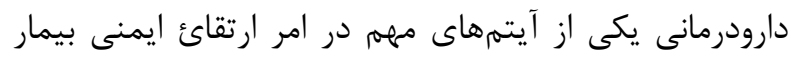

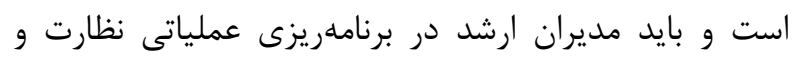

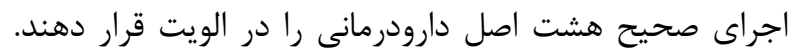

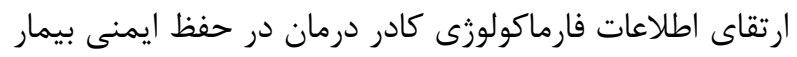

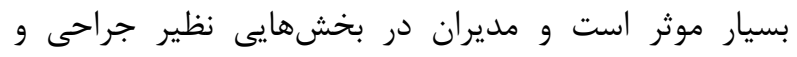

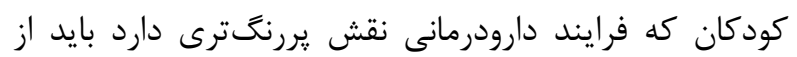
عواملى نظير اضافه كارى اجبارى، شيفتهاى متوالى و عدم

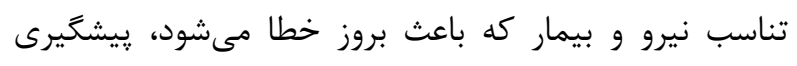

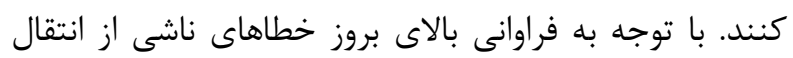

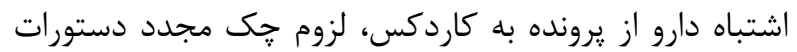

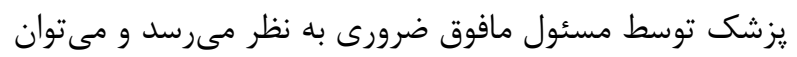

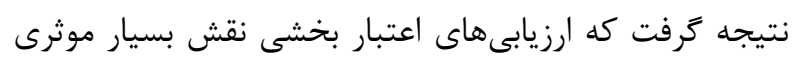

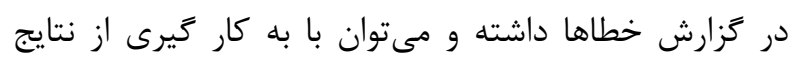

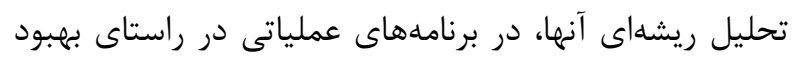

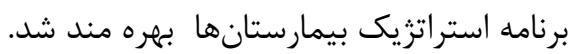

\section{تشكر و قدردانى}

بدين وسيله از جناب آقاى عباس مرادى براى تمامى زحمات

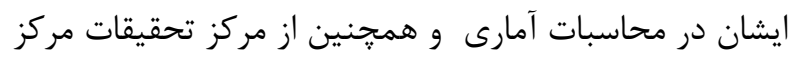

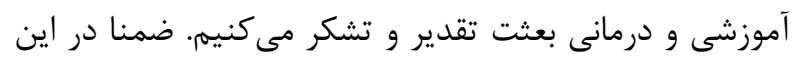
مطالعه تضاد منافعى كزارش نشده است.
يروهشخران اين مطالعه دريافتند كه بيشترين خطاهاى كزارش

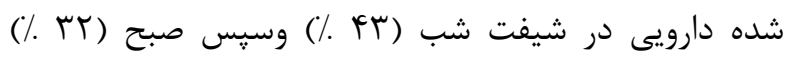

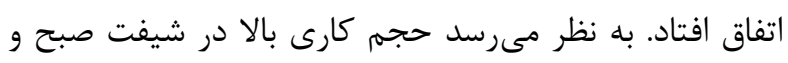

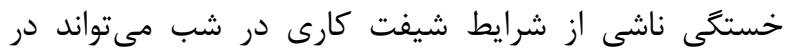
نتايج اين مطالعه موثر باشد. در بخشهايى نظير جراحى،

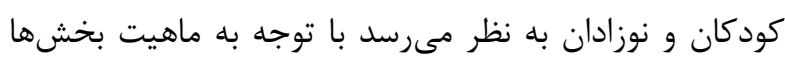

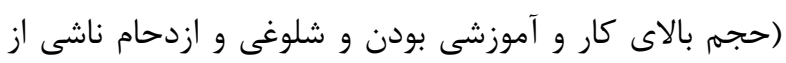
وجود دانشجويان از كروههاى مختلف و تعدد تجويز دستورات

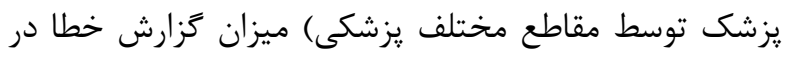

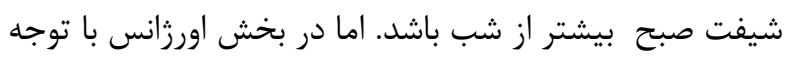
به تعدد بيشتر بيماران مراجعه كننده، اكثر موارد خطاهاى اين بخش در شيفت شب رخ داد. خماميا در مطالعه خود دريافت كه درصد بروز خداد خطا در شيفت

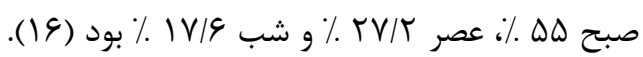
محسن زاده در مطالعه خود بيان مى كند كه شايعترين زمان

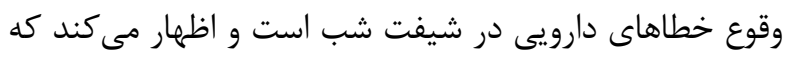
بروز هر نوع خطا به ماهيت بخش و بيمارستان بستكى دارد

در مطالعه آذرآباد و همكارانش بررسى كزارش خطاهاى

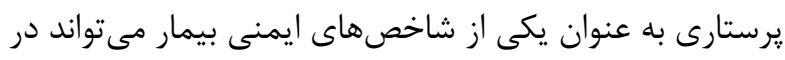

جلوكيرى از اشتباهات آينده مفيد باشد (iv (IV).

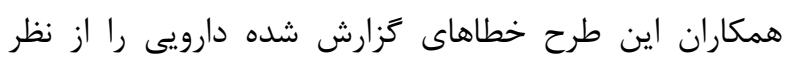

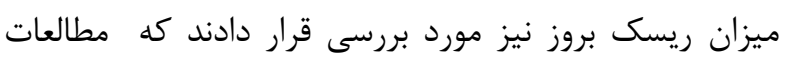

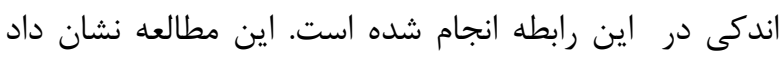

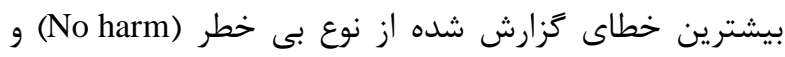

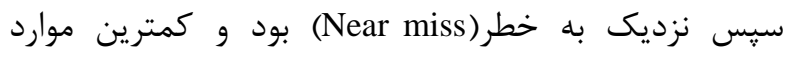

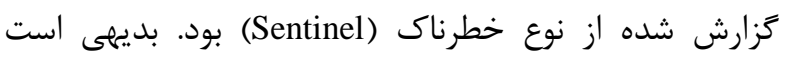

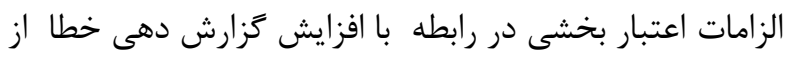

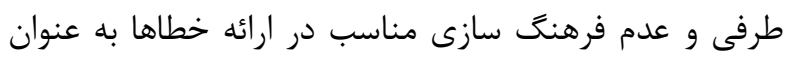

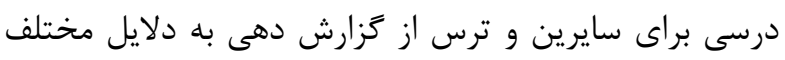

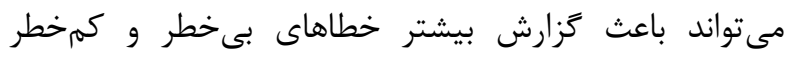

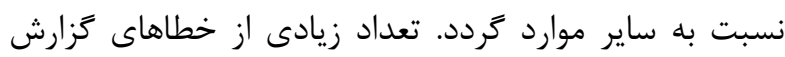

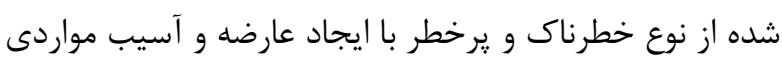

\section{REFERENCES}

1. Martinez Saghiry M. The role of medical errors reporting in medical errors management in Tehran Medical Science University hospitals. Daneshvar Medicine 2013;20:86-93. [In Persian]

2. Movahednia S, Partovishayan Z, Bastanitehrani M, Moradi F. Nurse Managers' perspectives about Reasons for not reporting medical errors in Firoozgar Hospital: 2012. RJMS 2014; 21:110-118. [In Persian]

3. Heydar pour P. family of tent of clinical governance, Tehran, Tandis Published 2011,40-45. [In Persian]

4. Vaziri S, Khansari P, Mansouri F, Afsharian M, Sayad B, Janbakhsh A, et al. Frequency and Types of Medical Errors in Infectious Patients Referred to the Emergency 24-Department of Imam Reza (AS) Hospital in Kermanshah, Iran (2014-2015). Journal of Patient Safety \& Quality Improvement. 2016;4:455-9. [In Persian] 
5. Banja J. Medical errors 101: A primer. The Case Manager 2005;16:57-9.

6. Jolaee S, Hajibabaee F, Peyravi H, Haghani H. Nursing medication errors and its relationship with work condition in Iran University of Medical Sciences. IJME 2009;3:65-76. [In Persian]

7. Siddiqi S, Elasady R, Khorshid I, Fortune T, Leotsakos A, Letaief M, et al. Patient Safety Friendly Hospital Initiative: from evidence to action in seven developing country hospitals. International Journal for Quality in Health Care. 2012;24:144-51. [In Persian].

8. Mohsenzade A, Rezapour S, Birjandi M. The prevalence of medical errors in children admitted to Madani hospital in the six months. Yafte 2009;11:31-38.[In Persian]

9. kouhestani H, Baghcheghi N. Refusal in Reporting Medication Errors from the Viewpoints of Nursing Students in Arak University of Medical Sciences. Iranian Journal of Medical Education 2009;8:285-292. [In Persian]

10. Hashemi F, Nikbakht Nasrabadi A, Asghari F. The obstacles of reporting nursing errors in Iran: a qualitative study. IJME 2011;4:53-64. [In Persian]

11. Rezaei Hachesoo P, Habibi S, Fozounkhah S. Information technology, an effective tool in reducing and preventing medical errors: suggestions for improvement. Health Inf Manag 2007;4:90-97. [In Persian]

12. Ross LM, Wallace J, Paton JY. Medication errors in a padiatric teaching hospital in the UK: five years operational experience. Arch Dis Child 2000;83:492-7.

13. Osmon S, Harris CB, Dunagan WC, Prentice D, Fraser VJ, Kollef MH. Reporting of medical errors: an intensive care unit experience. Crit Care Med 2004;32:727-33.

14. Mohammad Nejad I, Hojjati H, Sharifniya S H, Ehsani S R. Evaluation of medication error in nursing students in four educational hospitals in Tehran. IJME 2010;3:60-69. [In Persian]

15. Bagharian, H. Amount and reasons of medical errors in documented referral to legal medical of Esfahan. Journal of Health Administration. 2012;9:22-26. [In Persian]

16. Khammarnia M, Ravangard R, Ghanbari Jahromi , Moradi A.A Study on the Medical Errors in Public Hospitals of Shiraz. Patient Saf Qual Improv. 2016; 4:455-459. [In Persian].

17. Sh Azarabad, S S Zaman, B Nouri, S Valiee. Frequency, Causes and Reporting Barriers of Nursing Errors in the Operating Room Students. RME. 2018; 10:18-27. [In Persian]. 